\title{
Outsourcing the Welfare State: The Role of Private Actors in Welfare Fraud Investigations
}

\author{
Sofia Ranchordás* \\ Professor of European and Comparative Public Law; Rosalind Franklin \\ Fellow, University of Groningen, The Netherlands \\ s.h.ranchordas@rug.nl \\ Ymre Schuurmans \\ Full Professor of Constitutional and Administrative Law, Leiden University, \\ The Netherlands \\ y.e.schuurmans@law.leidenuniv.nl
}

\begin{abstract}
This article discusses the growing trend to employ private parties as informants, private detectives and providers of digital technology (e.g., automated risk assessments) to predict and investigate welfare fraud. In this article, we argue that this type of outsourcing is problematic for multiple reasons. First, private actors and governments often have an ill-defined contractual relationship which creates legal uncertainty and promotes the use of unconventional evidence-gathering instruments. This issue also raises concerns regarding the accountability of public bodies and the transparency and fairness of administrative procedure. Second, the private enforcement of antifraud regulations is susceptible of endangering the adequate pursuit of the public interest due to the misalignment of public and private interests. Third, the outsourcing of enforcement tasks to private technology companies and their opaque automated systems can be detrimental to the right to due process, the right to non-discrimination, and the privacy of welfare recipients. This article contributes to the literature with a novel critical account of how private actors are reshaping the welfare state.
\end{abstract}

* I would like to thank Catalina Goanta, Valery Gantchev, Mariolina Eliantonio as well as the anonymous reviewers for their insightful comments.

(C) SOFIA RANCHORDÁS \& YMRE SCHUURMANS, 2020 | DOI:10.1163/22134514-00701005

This is an open access article distributed under the terms of the prevailing CC-BY-NC License at the time of publication. 


\section{Keywords}

privatization - social welfare - algorithmic bias - data-driven decision-making discrimination - surveillance

\section{Introduction}

In October 2019, the newspaper The Guardian dedicated a full week to the "automation of poverty," describing governmental practices throughout the world that involve employing technology to watch closely welfare recipients. ${ }^{1}$ The use of digital technology and other surveillance techniques to prevent welfare fraud had been criticized months earlier by the UN Rapporteur on Extreme Poverty and Human rights as well as in recent literature on data-driven social security. ${ }^{2}$ The development of a digital risk assessment system ('SyRi') for welfare fraud prevention is also at the time of writing the subject of a judicial case in the Netherlands. ${ }^{3}$ This system helps predict which welfare recipients are more likely to abuse the system and should thus be investigated. ${ }^{4}$ Despite the alleged discriminatory character of SyRi, this system has been developed by Dutch public authorities and benefits from a relatively clear public legal framework. However, the same is not true for many other digital and analog techniques employed by private actors in welfare fraud investigations which are

1 E. Pilkington, 2019. 'Automating Poverty'. The Guardian, 14 October. Retrieved ${ }_{31}$ December 2019, https://www.theguardian.com/technology/series/automating-poverty.

2 UN Special Rapporteur on Extreme Poverty and Human Rights, Annual Report 2019. Retrieved $3_{1}$ December 2019, https://www.ohchr.org/EN/Issues/Poverty/Pages/AnnualReports .aspx. See also Human Rights Watch, May 2019 Submission to theUNSpecial Rapporteur on Extreme Poverty \& Human Rights Regarding His Thematic Report on Digital Technology, Social Protection \& Human Rights. Retrieved 29 July 2019, https://www.ohchr.org/EN/pages/home .aspx. V. Gantchev, 'Data protection in the age of welfare conditionality: Respect for basic rights or a race to the bottom?', European Journal of Social Security 21(1) (2019) (Gantchev) 3-22. https://doi.org/10.1177/1388262719838109.

3 The case is pending before the Court of first instance of The Hague. A decision is expected early 2019. For updated information on this case, see www.rechtspraak.nl.

4 Although this system has not yet succeeded at identifying well-founded cases of fraud, SyRi is perceived as a discriminatory tool to stigmatize welfare recipients, particularly nonWestern minorities. For an analysis of the information that is collected in this type of contexts and their societal impact, see S. Headworth, 'Getting to Know You: Welfare Fraud Investigation and the Appropriation of Social Ties', American Sociological Review 87 (2019) (Headworth) 171-196. 
often regulated through blurry contractual constructions. ${ }^{5}$ In this article we analyze the legal problems of outsourcing public law enforcement to private actors, particularly in the context of welfare fraud. This article delves into three common ways of involving private actors in welfare fraud prediction and detection: (i) as informants who tip-off public authorities on individuals who may be committing fraud; (ii) as private detectives who gather evidence on fraud; and (iii) as providers of automated systems that analyze data on citizens and predict the occurrence of fraud. ${ }^{6}$

Our focus includes welfare fraud investigations in the context of housing allowances for single-parents and students, unemployment benefits, and other benefits for illness and disability. Although this article is not strictly comparative, it seeks to show the growing relevance of the outsourcing of enforcement tasks to private parties with examples from the United Kingdom, Switzerland, United States, and the Netherlands. ${ }^{7}$ In these four jurisdictions welfare systems are liberal or have recently acquired traits of neoliberalism with the growing pressure to privatize certain parts of the system due to budget constraints. ${ }^{8}$ As this article shows, the use of these privatization methods has been welcomed differently in these countries. ${ }^{9}$ While in the Netherlands, the employment of private detectives has been harshly criticized in case law, in Switzerland, welfare legislation was recently amended to provide an explicit legislative framework to allow private detectives hired by social insurance bodies to monitor

5 Several data science companies offer data-analytics services for public bodies. Examples are Totta Data Lab or Ynformed. For literature on the privatization of social welfare, see, for instance, R. Forest and A. Murie, Selling the Welfare State: The Privatisation of Public Housing (London: Routledge, 1988); K.L. Moore, 'Privatization of Social Security: Misguided Reform', Temple Law Review 71(1) (1998) 129-170; M. Abramovitz, "The Privatization of the Welfare State: A Review', Social Works 31(4) (1986) 257-264; B. Romzek and J.M. Johnston, 'State social services contracting: Exploring the determinants of effective contract accountability', Public Administration Review 65(4) (2005) 436-449.

6 See J. Reeves, Citizen Spies: The Long Rise of America's Surveillance Society (New York: New York University Press, 2017) (Reeves).

7 See, for instance, K. Gustafson, Cheating on Welfare: Public Assistance and the Criminalization of Poverty (New York: New York University Press, 2011) (Gustafson); M. B. Katz, The Undeserving Poor: America's Enduring Confrontation with Poverty (Oxford: Oxford University Press, 2013). The trend to rely on private actors is also visible in several other countries: See, for instance, C. Aulich and J. O' Flynn, 'From Public to Private: The Australian Experience of Privatization', Asia Pacific Journal of Public Administration 29(2) (2007) 153-171.

8 J. B. Williamson, 'Privatization of Social Security in the United Kingdom: Warning or Exemplar?', Journal of Aging Studies 16(4) (2002) 415-430; R. B. DuBoff, 'The Welfare State, Pensions, Privatization: The Case of Social Security in the United States', International Journal of Health Studies 27(1) (1997) 1-23.

9 See also C. Donnelly, 'Privatization and Welfare: A Comparative Perspective', Law \& Ethics of Human Rights 5(2) (2011) (Donnelly) 1938-2545. 
welfare recipients anywhere in the public space. ${ }^{10}$ It is worth noting that in Switzerland there is already a strong collaboration between public and private institutions in the social security system (through private insurances). ${ }^{11}$ Despite the differences between these countries, in all of them (including Switzerland) the changing role of the Welfare State and the interaction between public and private parties therein are under discussion. ${ }^{12}$

This article offers primarily a critical reflection on privatization and how new forms of involving private actors in public law enforcement are reshaping the complex relationship between the State, society, and the market. ${ }^{13}$ This article does not aim to delve into automated decision-making and its technological intricacies or offer strict comparisons between social security systems which always involve a socio-political analysis. ${ }^{14}$ Rather, we address the larger problem posed by all three different types of involvement of private parties in the enforcement of social welfare laws: the illegitimate transfer of important public functions to private parties. ${ }^{15}$

This article engages with different strands of the international legal literature on privatization and outsourcing, the criminalization of social security

10 This legislative amendment occurred in response to the ruling of the European Court of Human Rights in the case Vukota-Bojić v. Switzerland, no. 61838/10, see Part II, ECHR 2016. The mentioned amendment was subject to a national referendum in November 2018, in which two-thirds of the population voted in favor of this enhanced form of fraud prevention.

11 M. Leimgruber, Solidarity without the State? Business and the Shaping of the Swiss Welfare State, 1890-200o (Cambridge: Cambridge University Press, 2012). C. F. Bertozzi and F. Gilardi, 'The Swiss Welfare State a Changing Public-Private Mix?' in D. Belard and B. Gran (eds), Public and Private Social Policy: Health and Pension Policies in a NewEU (Hampshire: Palgrave Macmillan, 2008) 207-227.

12 S. Rossini, 'Gouvernance de la sécurité sociale suisse. La politique sociale prise au piège de la pensé comptable', in: C. Bolzman, J. Libois and F. Tschopp (eds), Le travail social à la recherché de nouveaux paradigms (Geneva: IEs éditions, 2017), 87-103.

13 M. Leimgruber, 'Etat féderal, Etat social? L' histographie de la protection sociale en Suisse', Zeitschrift für Geschichte 18 (2011), 217-231.

14 See, for a thorough overview of the use of automated systems and big data in the prevention of welfare fraud, V. Eubanks, Automating Inequality: How High-Tech Tools Profile, Police, and Punish the Poor (New York: St. Martin's Press, 2018) (Eubanks). The reliance on automated systems is part of a broader trend in highly digitalized countries (e.g., Denmark): See C.S. Byrne and J. Sommer, 2019. 'Is the Scandinavian Digitalisation Breeding Ground for Social Welfare Surveillance?'. DataEthics, May 27. Retrieved 1 July 2019, https:// dataethics.eu/is-scandinavian-digitalisation-breeding-ground-for-social-welfaresurveillance/. On the challenges of comparing social security systems, see J. Dixon, 'Comparative social security: The challenge of evaluation', Journal of Comparative Policy Analysis: Research and Practice, 1:1 (1998), 61-95.

15 Given the growing importance of this topic, automated decision-making will be explored in future research. 
fraud, and the public-private divide. ${ }^{16}$ We contend that the binary lens of the public-private divide remains helpful but it does not foresee many of the potential risks of a broader outsourcing of public tasks, particularly in the digital age. ${ }^{17}$ This article is organized as follows: the first part delves into the specific nature of social security as a right and describes the evolution of the privatization trend in this sector. The second part focusses on the legal issues of employing private actors and their automated systems in the prevention and sanction of welfare fraud. The third part offers a normative framework for the privatization of public services. The fourth part concludes.

\section{The Privatization of Social Welfare}

\subsection{Social Security as a Right}

Social security systems were established in the twentieth century in multiple Western countries to address growing inequality and provide assistance to needy citizens. The right to social security is explicitly protected at international level in the European Social Charter, the UN Convention on Economic and Social Rights, the European Code of Social Security, the International Labor Organization (ILO) Convention No. 102. In the last decades we have observed the Europeanization of the right to social security as a result of the case law of the European Court of Justice of the European Union, the European Court of Human Rights ('ECtHR'), and the decisions of the European Committee of Social Rights. ${ }^{18}$

16 See, on privatization, providing an overview of the legal challenges of privatization in different fields, J. Freeman, 'Private Parties, Public Functions and the New Administrative Law', Administrative Law Review 52(3) (2000) 813-858 (Freeman); M.J. Trebilcock and E.M. Iacobucci, 'Privatization and Accountability', Harvard Law Review 116(5) (2002) 1422-1453; J. Freeman and M. Minow (eds), Government by Contract: Outsourcing and American Democracy (Cambridge, Mass: Harvard University Press, 2009). See also F. O'Carroll, 'Inherently Governmental: A Legal Argument for Ending Private Federal Prisons and Detention Centers', Emory Law Journal 67(2) (2017) 293-335 (O'Carroll).

17 S.M. Ford, 'Reconceptualizing the Public/private Distinction in the Age of Information Technology', Information, Communication \& Society 14(4) (2011) 550-567. See, generally, on the public/private divide, M. Lombard, 'La régulation et la distinction du droit public et du droit privé en droit français', in: M. Freedland and J-B. Auby (eds.), The Public Law/ Private Law Divide: Une Entente Assez Cordiale? (Oxford and Portland, Oregon: Hart Publishing, 2006) 81-89 at 83; S. Palmer, 'Public Functions and Private Services: A Gap in the Human Rights Protection', International Journal of Constitutional Law 6(3) (2008) 585-604.

18 G. Katrougalos, 'Social Security in the 'case law' of the Social Rights Committee', in: F. Pennings and G. Vonk (eds), Research Handbook on European Social Security Law (Cheltenham, UK and Northampton, Mass: Edward Elgar, 2015) 84-102. 
Social security is nowadays guided by two main principles both at the national and international levels: solidarity and equal treatment. ${ }^{19}$ These principles require inter-generational support, a fair distribution of income, social assistance for individuals who cannot earn an income, and prohibit discrimination. ${ }^{20}$ The main goal of social security and other social allowances is to alleviate poverty, support specific disfavored groups that might not be able to earn additional income (single parents) and invest in education (student allowances) ${ }^{21}$ This transfer of income is meant to promote individual freedom and distributive justice. ${ }^{22}$ The notion of social citizenship proposed by Marshall underlies still nowadays the concept of social welfare benefits and it requires that individuals are provided access to the necessary social and economic resources to participate in society. ${ }^{23}$ As McKeever explains, this implies not only having access to financial assistance but also being given the "freedom to make choices with knowledge of their consequences." ${ }^{24}$ For many, this state of freedom means transitioning back to the labor market, for others it simply means enjoying a minimum level of social and cultural participation.

\subsection{Social Welfare Fraud}

With the growing rise in social security expenditure, states have felt compelled not only to reduce the dependency of recipients on welfare services but also to control more rigorously their eligibility. ${ }^{25}$ Social security fraud varies from minor distortions of the truth by individual claimants on their eligibility to

19 P-Y. Greber, 'La sécurité sociale: une histoire, une culture, des défis: approche de droit international', Cahiers Genevois et Romands de la Sécurité Sociale 44 (2012) 9-28 at 21.

20 G. Vonck and M. Olivier, 'The Fundamental Right of Social Assistance: A Global, a Regional (Europe and Africa) and a National Perspective (Germany, The Netherlands, and South Africa)', European Journal of Social Security 21(3) (2019) 219-240.

21 G. McKeever, 'Social Citizenship and Social Security Fraud in the UK and Australia', Social Policy \& Administration 46(4) (2012) 465-482 (McKeever) at 470.

22 E. Eichenhofer, 'Social Security as a Human Right: A European Perspective', in: F. Pennings and G. Vonk (eds), Research Handbook on European Social Security Law (Cheltenham, UK and Northampton, Mass: Edward Elgar, 2015) 3-32.

23 T.H. Marshall, Citizenship and Social Class (Cambridge, England: Cambridge University Press, 1950) 7-10.

24 McKeever (n 21) 467.

25 According to a 2016 OECD report, public social spending amounted on average to $21 \%$ of the GDP of OECD countries: See OECD, 2018. 'Social Expenditure Database (socx) Update'. Retrieved 18 December 2018, http://www.oecd.org/social/expenditure.htm. See, for an overview of the costs of fraud prevention in different jurisdictions: C. van Stolk and E.D. Tesliuc, 2010. 'Toolkit on Tackling Error, Fraud, and Corruption in Social Protection Programs. World Bank. Retrieved 19 December 2019, http://siteresources.worldbank.org/ SOCIALPROTECTION/Resources/SP-Discussion-papers/Safety-Nets-DP/1002.pdf. 
welfare (e.g., submitting false documents for inexistent children, failure to report all of the earnings) to organized and sophisticated offences. ${ }^{26}$

In the United Kingdom, the United States, Switzerland, and in the Netherlands preventing and sanctioning social security fraud has been a priority for a number of years as fraudulent claims are estimated to amount to millions (if not billions) of dollars every year. ${ }^{27}$ Nevertheless, caseworkers are often too understaffed to investigate all recipients. ${ }^{28}$ Therefore, the success of social welfare fraud detection depends on obtaining high quality information about the lives of those who may be abusing the system. ${ }^{29}$ It is in this context that in the last decade multiple countries have urged citizens to come forward with tips on fraud and made significant investments in the creation of new task forces to combat fraud. Anti-fraud policies appear to be well-received by voters as they respond to the widespread public perception that social welfare recipients can play the system to their advantage and should thus be heavily penalized for doing so. ${ }^{30}$ Well-publicized scandals in the 1960 s, 1970 s and early 1980 s have contributed to the negative public image of welfare benefits and fraud mostly committed by women. ${ }^{31}$ From a broader perspective, it is worth noting that anti-fraud policies are also perceived as important as fraud undermines the basis of solidarity which is absolutely essential for the existence of a social security system.

In the Netherlands, the political pressure to combat welfare fraud has also increased significantly in the last decade. ${ }^{32}$ This has been fueled by multiple

$26 \quad$ McKeever (n 21) 466.

27 Ibid. at 141.

28 M. Button, 'Fraud Investigations and the 'Flawed Architecture' of Counter Fraud Entities in the United Kingdom', International Journal of Law, Crime and Justice 39(4) (2011) (Button) 249-265.

29 Headworth (n 4) 172.

30 See M.R. Rank, 'A View from the Inside Out: Recipients' Perception of Welfare', Journal of Sociology and Social Welfare 21(2) (1994) 27-47.

31 See, for a historical overview, M. Abramovitz, Regulating the Lives of Women: Social Welfare Policy from Colonial Times to the Present (Boston: South End Press, 1988); A. Pemberton, 'Discipline and Pacification in the Modern Administrative State: The Case of Social Welfare', Journal of Sociology \& Social Welfare 17(2) (1990) 125-142. See also D.E. Chunn and S.A.M. Gavigan, 'Welfare Law, Welfare Fraud, and the Moral Regulation of the 'Never Deserving' Poor', Social and Legal Studies 13(2) (2004) (Chunn and Gavigan) 219-243, 220; B. Baumberg Geiger, 'The role of knowledge and 'myths' in the perceived deservingness of social security benefit claimants', in: F. Roosma, B. Meuleman, and W. van Oorschot (eds), The Social Legitimacy of Targeted Welfare: Attitudes of Welfare Deservingness (Cheltenham, UK and Northampton, Mass: Edward Elgar, 2017) 73-92.

32 The Dutch legislator has, for example, required local governments to impose important financial sanctions on welfare recipients in any case of fraud (including minor violations 
recent fraud incidents involving individuals with an immigration background. In 2018 journalists reported on large-scale fraud of Eastern European individuals who applied for Dutch unemployment benefits, while taking long holiday breaks in their home countries. ${ }^{33}$ An investigation unveiling that a large number of welfare recipients were concealing real estate in Turkey also made the press headlines. ${ }^{34}$ Since 2015 the Dutch Court of Appeals has concluded in numerous cases involving Turkish nationals receiving welfare benefits but allegedly living abroad, that municipalities violated the prohibition to discriminate on the grounds of nationality. ${ }^{35}$ In May 2019, Dutch media reported that the Dutch Tax and Customs Administrations had tampered with evidence to cancel the child benefits of a significant number of parents with double nationality and a non-Western immigration background. ${ }^{36}$ Subsequent investigations confirmed that most of these parents were in fact eligible for the benefits they claimed, resulting in a public apology of the Minister of Finance for the seemingly discriminatory investigations, who admitted that "welfare fraud prevention was losing its human dimension." ${ }^{37}$ Indeed, although there are national variations, the popular perception of welfare fraud tends to be much higher than the reality: only a very small minority of welfare recipients abuses

of the duty to inform the authorities. In the Netherlands, local governments often are responsible for the administration of numerous social benefits, including the determination of eligibility and fraud prevention. Fraudulent welfare recipients are required to pay back the undeservedly received benefits and an additional fine which typically amounts to the same amount they received. In practice, fraudulent welfare recipients have to pay back the double amount. The Dutch Court of Appeals for Social Matters (Centrale Raad van Beroep, highest court in this case) considered that the statute dictating this outcome (Wet aanscherping handhaving en sanctiebeleid $s Z W$ ) was in breach of article 7 ECHR: See Centrale Raad van Beroep, November 24, 2014, ECLI:NL:CRVB:2014:3754.

'Widespread jobless benefit fraud in Polish community, Nieuwsuur says'. DutchNews 2018, September 4. Retrieved 15 July 2019, https://www.dutchnews.nl/news/2018/og/ widespread-jobless-benefit-fraud-in-polish-community-nieuwsuur-says/.

34 'Amper onderzoek naar bijstandsfraude Turken'. Binnenlands Bestuur 2018, October 20. Retrieved 19 December 2019, https://www.binnenlandsbestuur.nl/sociaal/nieuws/amperonderzoek-naar-bijstandsfraude-turken.95996o7.lynkx.

35 See, for an overview of these cases and the criteria applied, Dutch Court of Appeals for Social Matters, 'Wat is toegestaan bij onderzoek naar bijstandsfraude in het buitenland?'. De Rechtspraak. Retrieved 19 December 2019, https://www.rechtspraak.nl/Organisatieen-contact/Organisatie/Centrale-Raad-van-beroep/Nieuws/Paginas/Wat-is-toegestaanbij-onderzoek-naar-bijstandsfraude-in-het-buitenland.aspx.

36 'Belastingdienst zette kinderopvangtoeslag stop naar aanleiding van achterhaalde informatie'. Trouw 2019, May 29. Retrieved 15 July 2019, https://www.trouw.nl/nieuws/ belastingdienst-zette-kinderopvangtoeslag-stop-naar-aanleiding-van-achterhaaldeinformatie $\sim$ b3196a67/. 
the system (between 2 and $10 \%$ in the United States, United Kingdom, and the Netherlands). ${ }^{38}$ Moreover, intrusive, rigid and unclear anti-fraud strategies tend to be counterproductive as they do not distinguish between a needy citizen who unknowingly made an honest mistake and organized crime. This approach deteriorates the relationship between citizens and their governments. ${ }^{39}$

Welfare fraud is typically sanctioned with administrative sanctions such as the immediate cancelation of benefits along with other administrative penalties (e.g., ineligibility for welfare support for a certain period, or, more rarely, permanent disqualification for life from welfare). In addition to these civil or restitution penalties, several countries (e.g., United States, the Netherlands) impose criminal penalties for welfare fraud, prosecuting the most serious forms of intentional and willful misrepresentation. The current "criminalization of welfare fraud" also includes a number of enforcement practices such as rules on the burden of proof, enhancement of enforcement tasks and reinforcement of surveillance of welfare recipients by undercover enforcement officers. ${ }^{40}$ In the United States, federal welfare legislation further limits the eligibility for aid for adults with drug felony convictions. ${ }^{41}$

In the next section, we delve into the employment of private actors in the context of fraud-prevention and enforcement.

38 See, for the United States: Department of Labor. 'Improper payment data for the Unemployment Insurance (UI) program derived from the Benefit Accuracy Measurement (вАм) program for the 12-month period ending March 31, 2014 (2014)'. Retrieved 19 December 2019, http://www.dol.gov/dol/maps/Data.htm. For information on the United Kingdom: Department for Work and Pensions. 'Annual Report and Accounts 2012-13'. The Stationery Office, London, 2013. Retrieved 19 December 2019, https://assets.publishing .service.gov.uk/government/uploads/system/uploads/attachment_data/file/264555/ dwp-annual-report-accounts-2012-2013.pdf. For the Netherlands: P. de Winter, Tussen de Regels: Een rechtssociologische studie naar handhaving in de sociale zekerheid[Between the Rules: A Socio-legal Study of Law Enforcement in Social Welfare] (Groningen: Boomjuridisch, 2019) [in Dutch].

39 See, for an empirical study in the Netherlands, M. Hertogh, Slimme Handhaving [Smart Enforcement] (The Hague: Boom juridisch, 2018). According to this study, aggressive fraud-combat strategies are not as effective as it is commonly thought. This empirical study shows that most welfare recipients comply with their obligations. Welfare fraud prevention mechanisms are experienced as a form of 'policing' rather than positive coaching which help them live independently from welfare. The study also shows that there is no clear correlation between repressive enforcement and compliance).

40 Chunn and Gavigan (n 31) 220; Gustafson (n 7) 51-52.

41 Gustafson (n 7) 55 . 
Public bodies and their civil servants are traditionally regarded as the primary agents of public law enforcement. However, the prosecution of fraud is complex, fragmented, time consuming, and it requires having "eyes and ears" everywhere. ${ }^{42}$ Public actors have thus resorted to citizens and professional private investigators in a wide variety of fields. ${ }^{43}$ Although private actors have received limited attention from legal academia, these private agents outnumber their public sector counterparts. ${ }^{44}$

In the twentieth century, private investigators reemerged as private security companies started offering specialized services and expertise to airports (e.g., for terrorism prevention), large corporations, and shopping malls. ${ }^{45}$ Private investigators are currently hired by governments and individuals to gather and examine facts in order to reconstruct past events in an efficient and accurate way. ${ }^{46}$

Private investigators are broadly employed in the United States, United Kingdom, the Netherlands and Switzerland by corporations and insurance companies to investigate fraudulent disability and illness claims. ${ }^{47}$ These actors have also been strategically used in the context of financial crime investigations which are often carried out by global auditing firms. ${ }^{48}$ Private investigators tend to benefit from their previous experience as former police agents, intelligence officers or highly-skilled IT-specialists. ${ }^{49}$ Moreover, private

42 M. Button, D. Shepherd and D. Blackbourn, "The Iceberg beneath the Sea', Fraudsters and Their Punishment through Non-criminal Justice in the 'Fraud Justice Network in England and Wales", International Journal of Law, Crime and Justice 53 (2018) 56-66 at 57.

M. Gill and J. Hart, 'Exploring Investigative Policing: A Study of Private Detectives in Britain', British Journal of Criminology 37(4) (1997) 549-567.

44 M. Button and B. George, 'Government regulation in the United Kingdom private security industry: The myth of non-regulation', Security Journal 14(1) (2001) 55-66.

45 M. Button, 'Assessing the Regulation of Private Security across Europe', European Journal of Criminology 4(1) (2007) 109-128 at 109-111.

46 See P. Gottschalk, Understanding White-Collar Crime: A Convenience Perspective (Boca Raton: CRC Press, 2016).

47 See A. Stenström, 'The Private Policing of Insurance Claims: Power, Profit and Private Justice', British Journal of Criminology 58(2) (2018) 478-496, discussing, on the grounds of an empirical study, how private policing are used to protect the profit of insurance companies. See also M.K. Nalla and G.R. Newman, 'Public versus private control: A Reassessment', Journal of Criminal Justice 19(6) (1991) 537-547.

48 P. Gottschalk, 'Blame Game and Rotten Apples in Private Investigation Reports: The Case of Hadeland and Ringerike Broadband in Norway',Journal of Investigative Psychology and Offender Profiling 13(2) (2016) 91-109.

House of Commons-Home Affairs Committee. 'Private Investigators: Fourth Report of Session 2012-13'. House of Commons. Retrieved 27 December 2018, https://publications 
investigators are cost-effective as they are only hired when required. In the United Kingdom, some police forces have experimented with procuring services previously carried out by police officers in order to face government cuts. $^{50}$

Private investigations in the context of fraud prevention tend to be goaloriented procedures which start out from the suspicion of fraud or misconduct and they are desirably based on a mandate defined by and with the client. ${ }^{51}$ The work of private investigators is thus limited in scope and should ideally deliver independent, careful, and transparent work. These investigators report back to private corporations that, in case of administrative or criminal fraud, can suggest that public bodies initiate an investigation. In Switzerland and in the Netherlands, social insurance companies and public bodies that are responsible for welfare benefits, have relied on similar private policing mechanisms to investigate social welfare fraud..$^{52}$ Employing private detectives has multiple advantages: first, contracts between public bodies and private agents allow companies to work around existing policies and operate with greater unilateral policy discretion. ${ }^{53}$ Second, some of these private investigators operate on the grounds of performance-based contracts, that is, their remuneration is dependent on the ability to detect fraud. ${ }^{54}$ While some of these companies are licensed and subject to special legislation, the activity of several others remains fully unregulated and can only be sanctioned by applying general private law dispositions..$^{55}$

.parliament.uk/pa/cm201213/cmselect/cmhaff/10o/10o.pdf. According to this report, $65 \%$ of private investigators are former police officers.

50 House of Commons - Home Affairs Committee. 'The Role of the Private Investigator'. House of Commons. Retrieved 26 December 2018, https://publications.parliament .uk/pa/cm201213/cmselect/cmhaff/100/10005.htm\#note13.

51 P. Gottschalk, 'Limits to Private Internal Investigations of White-Collar Crime Suspicions: The Case of Scandinavian Bank Nordea in Tax Havens', Cogent Social Sciences 2(1) (2006) $1-14,3$.

52 See, for an international perspective, J. De Waard, 'The Private Security Sector in Fifteen European Countries: Size, Rules and Legislation', Security Journal 4(2) (1993) 58-73. See, for a thorough analysis of private security, M. Button, Private Policing (Cullompton:Willan Publishing, 2002).

53 J.D. Michaels, 'Privatization's Pretensions', University of Chicago Law Review 77(2) (2010) $717-780$ (Michaels) at 719 .

54 Dutch Administrative High Court, September 16, 2014, ECLI:NL:CRVB:2014:2947. See also First-instance Court of Rotterdam, 6.10.2015, ECLI:NL:RBROT:2015:7050 http://uitspraken .rechtspraak.nl/inziendocument?id=ECLI:NL:RBROT:2015:7050\&keyword=investiga [in Dutch].

55 Wet particuliere beveiligingsorganisaties en recherchebureaus [Statute on private security organizations and investigators], October 24, 1997, Stb. 1997, 500. These enterprises are often consultancy agencies, who share knowledge with, advise, and educate the public 
The involvement of private detectives and the use of technology developed by private companies are not the typical forms of privatization and outsourcing of public tasks that the literature has analyzed for the past decades. Therefore, these new forms of outsourcing of public tasks raise novel questions as to the admissibility and the legitimacy of private actors. ${ }^{56}$ In this part, we describe the involvement of private actors in welfare fraud investigations and inquire into the reasons why relying on private actors and their high-end surveillance techniques may be problematic from a legal perspective.

\subsection{Private Actors as Informants}

"If you see something, say something" is a well-known appeal to citizens to report suspicions of terrorist threats, provide tips to police regarding fugitives, and report fraud. ${ }^{57}$ These authorities coopt citizens' sight, speech, and social networks as in the context of social welfare fraud, valuable information tends to come from informants who are close to the recipients. ${ }^{58}$ Citizens are endowed with unique intelligence gathering that can complement the state's enforcement powers, they have access to private information, and are likely to hear what welfare recipients would never disclose to a public authority. ${ }^{59} \mathrm{In}$ the last years, public authorities have even relied on gamification applications to make citizen involvement in law enforcement more appealing. ${ }^{60}$

Citizens can be involved in different ways in the context of welfare fraud investigations: first, welfare authorities in multiple countries encourage citizens to come forward voluntarily with information on abusive claims. In the United Kingdom, citizens can report their suspicions through the Department for Work and Pensions (DWP) Fraud and Error Service and use the National

sector and also offer services in fraud investigations. Three major players on the Dutch market are SV Land, Langhenkel, and Bureau Buitenland.

56 See, generally, J. Freeman and M. Minow, 'Introduction: Reframing the Outsourcing Debates', in: J. Freeman and M. Minow (eds), Government by Contract: Outsourcing and American Democracy (Cambridge, Mass: Harvard University Press, 2009) 1-20 at 8; E.S. Savas, Privatization: The Key to Better Government (Chatham: Chatham House, 1987) 112. See also, criticizing the new forms of privatization, J.D. Michaels, 'Privatization's Progeny', Georgetown Law Journal 101(4) (2013) 1023-1088.

57 Reeves (n 6) 3.

58 Headworth (n 4) 171-174.

59 Reeves (n 6) 10-11.

6o The Dutch police in particular has released two applications that incentivize citizens to get involved in the detection of stolen cars with the application 'Automon' or solve cold cases with 'Sherlock'. See J. Milaj and G.J. Ritsema van Eck, 'Capturing Licence Plates: Police-Citizen Interaction Apps from an EU Data Protection Perspective', International Review of Law, Computers and Technology (2019) https://doi-org.proxy-ub.rug.nl/10.1080/1 3600869.2019.16oo335. 
Benefit Fraud Hotline. Similar services exist in the Netherlands, Switzerland, and the United States and are widely used by citizens. The Swiss National Accident Insurance Fund (Suva), one of the pillars of the country's social security system, alone receives per year around 1700 tips of potential fraud. ${ }^{61}$ In many cases, the tips provided refer to neighbors, (former) partners, family members, and close acquaintances. With the development of social media (e.g, Facebook), citizens have also become "digilantes" as they use their online networks to report on members of their networks. ${ }^{62}$

Citizens can also be involved as informal informants in the context of interviews conducted by investigators. ${ }^{63}$ In several situations, citizens may not be aware that they are putting at stake the welfare benefits of their neighbors or acquaintances. It has been reported that investigators in the United States have at times used subterfuges to obtain the information they need to detect fraud or have adapted information to fit the context of their investigation. ${ }^{64}$ While omitting information may encourage individuals to be more frank with public authorities, it generates legal uncertainty and raises questions as to the legality of the evidence gathered in the context of investigations. ${ }^{65}$

The appeal to the civic duty to report fraud has been a source of criticism for decades. ${ }^{66}$ First, a significant number of tip-offs are driven by malice and the wish to take personal revenge on welfare recipients. In addition to the potential conflict of interests, there is also the risk of overenforcement and underenforcement. ${ }^{67}$ The clear misalignment of interests between public

61 SUvA, 'Lutte contre la fraude à l'assurance'. suva. Retrieved 19 December 2019, https:// www.suva.ch/fr-ch/la-suva/autoportrait/lutte-contre-la-fraude-a-l-assurance.

62 S. Lageson and S. Maruna, 'Digital Degradation: Stigma Management in the Internet Age', Punishment and Society 20(1) (2018) 113-133. "Digilantes" refers in other contexts to a growing Internet subculture that seeks extrajudicial punishment for cybercriminals: See D.N. Byrne, ' 419 Digilantes and the Frontier of Radical Justice Online', Radical History Renew 117 (2013) 70-82.

63 See J. Gilliom ( $\mathrm{n}_{14}$ ), describing the constant surveillance welfare recipients are subject to and the role of social control.

64 Headworth (n 4) 174, 184.

65 J.M. Burkoff, 'Not So Private Searches and the Constitution', Cornell Law Review 66(4) (1981) 627-672 (Burkoff).

66 See, generally, Reeves (n 6).

67 M.E. Gilles, 'Reinventing Structural Reform Litigation: Deputizing Private Citizens in the Enforcement of Civil Rights', Columbia Law Review 10o(6) (2000) 1384-1453. See, on underenforcement, B.H. Thompson Jr., 'The Continuing Innovation of Citizen Enforcement', University of Illinois Law Review (2000(1)) 185-236 at 204-06. See also D. Bowen Matthew, 'The Moral Hazard Problem with Privatization of Public Enforcement: The Case of Pharmaceutical Fraud', University of Michigan Journal of Law Reform 40(2) (2007) 281-340 (Bowen Matthew) at 338. 
authorities and citizens allows informants to mobilize public authority for personal purposes. ${ }^{68}$

Second, welfare fraud enforcement teams face a large number of tip-offs which they are not able to pursue because citizens often provide inaccurate information. ${ }^{69}$ Only a small number of welfare recipients are investigated depending on the type of evidence that has been gathered against them. ${ }^{70}$

Third, empirical research in the United Kingdom has shown that after citizens have provided tips, the triage of cases that will be pursued is still done with great discretion. ${ }^{71}$ Investigators tend to decide on the grounds of their experience whether a case is worth pursuing or not. In simple cases it was found that investigators suffer from a strong confirmation bias as they try to find corroborating evidence for a tip-off-regardless of the motives that drove the denunciation-rather than to look for alternative explanations for the breach under investigation. Moreover, the ubiquitous character of the involvement of citizens affects the procedural guarantees of social welfare recipients who can be invisibly controlled at all times by neighbors, acquaintances, and friends in the intimacy of their private sphere. ${ }^{72}$ In conclusion, citizens' collaboration with public authorities allows investigators to tap into the private spheres of welfare recipients but it also subjects them to a high level of social control and allows individuals to use law enforcement for their personal gain.

\subsection{Private Actors as Detectives}

While many countries appeal to citizens' input in their investigations, not many Western governments have taken a step in the direction of hiring private detectives for fraud investigations. This has occurred for example in the Netherlands and Switzerland. As this section explains, the employment of

68 Headworth (n 4) 183. See R. Donyets-Kedar, 'Rethinking Responsibility in Private Law', in: M. Albertson Fineman, T. Mattson, and U. Anderson (eds), Privatization, Vulnerability, and Social Responsibility (Boca Raton: CRC Press, 2016) section I.(4).

69 H. Koskela, "Don't Mess with Texas!': Texas Virtual Border Watch Program and the (botched) politics of responsibilization', Crime, Media, Culture 7(1) (2011) 49-65 (Koskela) at 59 .

70 English media reported for example in 2018 that 280,000 public tip-offs did not result in any significant action against the reported welfare recipients due to lack of evidence: 'Benefit Fraud 'Witch Hunt': 280,00o Public Tip-Offs Led to No Action Taken due to Lack of Evidence'. The Independent 2018, January 15. Retrieved 25 July 2019, https://www .independent.co.uk/news/uk/politics/benefit-fraud-public-tip-offs-legal-action-policeno-evidence-dwp-work-pensions-department-a8144096.html.

71 D. Walsh, C.J. Dando, and T.C. Ormerod, 'Triage Decision-Making by Welfare Investigators', Journal of Applied Research in Memory and Cognition 7(1) (2018) 82-91. 
private detectives can have a considerable impact on the procedural guarantees of the subjects under investigation.

\subsubsection{Legal Basis}

In the past seven years, Dutch administrative courts have reviewed a number of administrative decisions that were directly or indirectly based on investigations conducted by private actors. ${ }^{73}$ In several of these cases, the admissibility of the evidence obtained by these private investigators was disputed due to the inexistence of a specific legal basis for their operation or unclear contractual relationship. ${ }^{74}$

The admissibility of the evidence gathered by private detectives depends first of all on the existence of a legislative or contractual basis. Depending on the existence of these legal elements, private agents may benefit from legal frameworks that are typically applied to private actors rather than public bodies. ${ }^{75}$ In other words, contrary to public enforcement agents, private investigators who are not operating on behalf of public authorities can gather evidence through a wide array of techniques without prior judicial authorization. ${ }^{76}$ They may not seize documents but upon receiving authorization to enter a home, private investigators may take pictures of available evidence.

In the case Vukota-Bojic before the ECtHR, a Swiss social insurance company had hired a private detective to secretly monitor a welfare recipient who was suspected of misinforming the authorities about her physical inability to work. ${ }^{77}$ Private investigators followed her for several days and prepared a detailed monitoring report containing images and videos of the welfare recipient. ${ }^{78}$ The applicant in this case argued that the secret surveillance by private detectives violated her rights under Articles 6 and 8 ECHR and that the

73 See, for instance, Centrale Raad voor Beroep [Dutch High Court for Social Affairs] 16 January 2014, ECLI:NL:CRVB:2014:191 (mystery guest); ABRvS [Dutch Council of State, Administrative Law Division] ${ }_{15}$ February 2012, ECLI:NL:RVs:2012:BV5541.

74 See, for instance, Dutch Administrative High Court for Social Affairs [Centrale Raad van Beroep] - See AB 2014/422, Centrale Raad van Beroep, 16 September 2014, ECLI: NL:CRVB:2014:2947: in this case, the Dutch Administrative High Court decided that a local public body in charge of controlling the eligibility of housing allowances benefits should not be allowed to outsource the control of social welfare benefits to a commercial company with whom it merely had a "no cure [fraud], no pay" relationship.

75 K. Brennan-Marquez, 'The Constitutional Limits of Private Surveillance', University of Kansas Law Review 66 (2018) (Brennan-Marquez).

76 C.A. Meerts and N. Dorn, 'Corporate Security and Private Justice: Danger Signs', European Journal of Crime, Criminal Law and Criminal Justice 17(2) (2009) 97-111 at 104.

77 Vukota-Bojić v. Switzerland, no. 61838/10, ECHR 2016.

$78 \quad$ Ibid, § 35 . 
information gathered should be excluded as illegally obtained evidence. Under Swiss federal law, this social insurance company was qualified as a public authority and was thus obliged to respect Swiss public law and the ECHR. There was nonetheless no legislative basis for the surveillance of citizens in cases of fraud and no information regarding the maximum duration of the surveillance measures or the possibility to challenge them in court. Public authorities had thus broad discretion in deciding which circumstances justified such surveillance and for how long.

While the ECtHR did not delve into the particular use of private investigators to conduct this far-reaching investigation, it insisted on the need for legal provisions that legitimize this type of interference with an individual's right to private life..$^{79}$ When a public authority hires private detectives, it must guarantee that their investigative actions respect the same restrictions and comply with equal safeguards as when it acts with its own civil servants. While the Court did not discuss the contractual relation between the public authority and the private detectives in the Vukota-Bojic case, it can be expected that the lack of a formal hierarchy and oversight of all actions of the private detectives will increase the risk of abuse of secret surveillance measures.

As a response to the Vukota-Bojic judgment, the Swiss legislator has provided a legislative basis for the operation of private detectives in welfare fraud investigations in the context of accidents and disability (Articles $43 \mathrm{a}, 43 \mathrm{~b}$ and 79 al. 3). ${ }^{80}$ Surveillance is currently allowed in public spaces, which includes balconies and gardens; private detectives may use drones, G PS and other trackers provided that they request judicial authorization beforehand; and surveillance must be limited to the period of thirty days per six months. With the enactment of a detailed legislative basis for surveillance, the judgment of the ECtHR contributed to the clarification of the expectations of Swiss beneficiaries but not necessarily to the improvement of their right to private life. This law does not fully exclude the use of illegally obtained evidence to prove welfare fraud. In other words, if a detective violates the limits of new legal basis to gather evidence of fraud, its use may still be up for debate. ${ }^{81}$

In the Netherlands, the Dutch legislator has provided a broad legal basis for the involvement of private actors in social welfare administration as long as

79 See, for an analysis of the implications of this ECtHR case for the data protection of individuals, J. Evers, 'Foreseeing Secret Surveillance in Social Security: Setting the Record Straight', European Data Protection 3(4) (2017) 550-554.

8 o Loi fédérale sur la partie générale du droit des assurances sociales (LPGA) du 6 octobre de 2000, RO 2019 2829, FF 201770037021.

81 See also the decision of the Swiss Federal Case on a case similar to Vukota-Bojic concerning the obtainance of illegal evidence by a detective, ATF 9C_806/2016. 
the core public tasks - the decisions to grant and re-claim benefits- remained in the hands of public authorities. ${ }^{82}$ An explicit legislative basis in the sense of the Vukota-Bojic judgment, can only be found in limited areas of welfare administration (e.g., student allowances). In the Netherlands, courts have tried to safeguard the legality of the outsourcing of public tasks to private investigators not only by interpreting the existing legal basis but also by inquiring into the contractual relationship between public authorities and private detectives in order to establish the degree of public intervention in each specific case.

In the United Kingdom, local public bodies have been reported to also hire private detectives for fraud investigations. ${ }^{83}$ We have identified a number of private companies that offer to gather evidence and provide expert testimony in welfare investigations. ${ }^{84}$ These services include obtaining proof of cohabitation to support evidence fraud. On the website of one of these private detective companies, it is stated that proof of cohabitation "is needed for the council to take further action as they cannot do anything without it. If you are able to prove this, then you can get justice for yourself and other UK tax payers in London." ${ }^{85}$ Drawing on the information available on this and other private detective websites, we could conclude that the evidence gathered by private detectives is used to initiate investigations and detect both small and large scale fraud cases. ${ }^{86}$ In the United Kingdom, investigation and surveillance practices are subject to the limits defined by the Social Security Fraud Act 2001 (and further elaborated in the Code of Practice on Obtaining Information), the Regulation of Investigatory Powers Act 2000 as well as the Human Rights Act which makes it unlawful for a local authority to breach any article of the European Convention of Human Rights. ${ }^{87}$ While this legal framework was not directly designed for the actions of private detectives, these rules are applicable to the Authorized Officers responsible for outsourcing

$82 \quad$ Pg Awb III, p. 334 (additional clarification article 5:11 GALA) and KamerstukkeniI [Dutch Parliament Papers, House of Representatives], 2002/03, 28 870, nr. 3 p. 37.

83 H. Furness, 2012. 'Councils spend £1m hiring private detectives'. The Telegraph, February 28. Retrieved 7 January 2020, https://www.telegraph.co.uk/news/politics/9111049/Councils-spend-1m-hiring-private-detectives.html.

84 This is the case of EuroTech Investigation Service, see http://www.euro-tecinvestigationservice.co.uk/welfareinvestigations.html; and Insight, see https://www.investigate.uk/ observations/ (retrieved 30 December 2019).

85 London Private Detectives. Retrieved 30 December 2019, https://london-privatedetectives.co.uk/investigations-in-london/proof-of-cohabitation/.

86 EJM Investigations. Retrieved 30 December 2019, https://www.ejminvestigations.co.uk/ benefit-fraud.html.

87 See J. Rosenblom, 'Local Benefit Fraud', in: A. Doig (ed.), Fraud: The Counter Fraud Practitioner's Handbook (London: Routledge, 2012) 157-188. 
investigations. ${ }^{88}$ When the legal framework does not apply directly to private detectives, it is important to analyze the underlying contractual relationship between public bodies and private actors. In other words, the existence of a legal basis for the employment of private detectives does not exclude the need for a clear contract between these private actors and public authorities. In 2014, the Dutch High Court for Social Affairs excluded the evidence of fraud collected by the private detectives, as it had been obtained "in violation of the principles of good administration." ${ }^{\prime 89}$ The relationship between public and private bodies was in that specific case unclear and the court could not assert whether the detectives had received clear instructions and supervision from the public authority that was ultimately accountable to the investigation. Furthermore, the private detectives only had in this case a performance-based contract which provided strong incentives to find evidence of fraud and raised one of the oldest questions in the context of privatization: the divergence of incentives between private actors (maximize profit) and the pursuit of the public good. ${ }^{90}$ In this case, the Court excluded it based on the contractual relationship between the parties and the need to draw limits to the outsourcing of public tasks. ${ }^{91}$ In other Dutch cases of welfare fraud involving private detectives, the outsourcing to private agents was based on specific legislative and contractual dispositions and it was proven the public body gave specific instructions on what kind of investigative measures could be undertaken. ${ }^{92}$

88 Department of Work and Pensions, 2016. 'Social Security Fraud: Code of Practice on Obtaining Information'. Retrieved 7 January 2020, https://www.gov.uk/government/publications/social-security-fraud-code-of-practice-on-obtaining-information.

89 Centrale Raad van Beroep, 16 September 2014, ECLI:NL:CRVB:2014:2947.

9o See J.B. Goodman, and G.W. Loveman, 'Does Privatization Serve the Public Interest?', Harvard Business Review, Nov-Dec (1991) https://hbr.org/1991/11/does-privatization-serve-thepublic-interest. See also J. Barkan, Corporate Sovereignty: Law and Government under Capitalism (Minneapolis: University of Minnesota Press, 2013).

91 The court considered that the evidence supporting the decision of the public body was illegally obtained and violated Article 7(4) of the Dutch Statute on Employment and Social Benefits (Wet werk en bijstand). See, for further information on evidence gathering in Dutch administrative law, Y.E. Schuurmans, 'Onrechtmatig verkregen bewijsmateriaal in het bestuursrecht' [Illegally Obtained Evidence in Dutch Administrative Law], Ars Aequi (May 2017) 388-399 [in Dutch].

92 See, for instance, First-instance court of Rotterdam, 6.10.2015, ECLI:NL:RBROT:2015:7050 http://uitspraken.rechtspraak.nl/inziendocument?id=ECLI:NL:RBROT:2015:7050\&keywo rd=investiga [in Dutch]; Centrale Raad van Beroep, 2 december 2015, AB 2016/77 (m.n.v. H. E. Bröring). The Dutch Administrative High Court (Centrale Raad van Beroep) is the court of appeal for a part of the administrative disputes in the Netherlands. It judges cases governed by the General Administrative Law Act (Algemene wet bestuursrecht) and it is in particular competent to decide appeals involving social security and social assistance disputes. 
When this hierarchical or employment relationship is verified, private investigators are nonetheless not allowed to go beyond the limits of what would be allowed to a public enforcement agent.

In the United States, a number of states have recently started enacting legislation to allow private companies to investigate public assistance fraud. This is the case of Illinois, Mississippi, Missouri, and Wyoming which recently passed laws allowing these state to hire a private contractor to check the eligibility of individuals participating in state public assistance programs like Medicaid. ${ }^{93}$ These private actors are contracted for the use of 'computerized control systems' and may simply alert the state that a person is ineligible for welfare. State legislation defines the scope and limits of the outsourcing of powers.

To conclude, the existence of a clear legal basis is essential to legitimize the involvement of both public and private actors in surveillance activities. It is worth noting that in December 2019, the ECtHR also discussed the degree of specificity of judicial authorizations to conduct surveillance, stating that "the Court is of the opinion that secret surveillance being a serious interference with a person's right to respect for private life, a judicial authorisation serving as its basis cannot be drafted in such vague terms as to leave room for speculation and assumptions with regard to its content and, most importantly, to the person in whose respect the given measure is being applied ${ }^{94}$

\subsubsection{Evidence-gathering and Fundamental Rights}

Outsourcing has allowed public institutions to expand the scope of their enforcement powers and benefit from the more generous legal framework applicable to private actors, for example, in the context of evidence gathering. ${ }^{95}$ Evidence-gathering in administrative procedures is in general characterized by fairly lenient limits as long as the public body collects the necessary information according to the general principles of good administration (e.g.,

93 J. Fifield, 'What Happens When States Go Hunting for Welfare Fraud', Pew Research Center (May 24, 2017), available at https://www.pewtrusts.org/en/research-and-analysis/ blogs/stateline/2017/05/24/what-happens-when-states-go-hunting-for-welfare-fraud . See, for example, HOPE (Act to Restore Hope Opportunity and Prosperity for Everyone), Mississippi Legislature, 2017, http://billstatus.ls.state.ms.us/documents/2017/html/HB/ 1000-1099/HB109oPS.htm, Section 3.

94 Hambardzumyan v. Armenia (Application no. 43478/11) ECHR 417 [2019] § 65.

95 The limits of evidence-gathering tend to be even more lenient when evidence is gathered by private parties. For example, in the United States, private investigators will not be bound by the Fourth Amendment; therefore, information uncovered by private citizens without the consent of the investigated party may still be admissible in court. See Brennan-Marquez (n 75) 485-522. 
transparency). ${ }^{96}$ The absence of clear limits to evidence gathering is particularly challenging in the field of social welfare as much of this evidence does not meet national criminal law standards. This information can nonetheless be used indirectly to initiate the prosecution of a citizen for welfare fraud crimes. ${ }^{97}$ Furthermore, evidence-gathering strategies used by private investigators (such as the thorough surveillance described in the Vukota-Bojic case) are likely to put at stake a number of fundamental rights, particularly national procedural guarantees (due process, equality of arms) and the right to respect for private and family life (including privacy). ${ }^{98}$

Although the ECtHR in the Vukota-Bojic case found a breach of the right to respect for private life (and hence privacy) in intrusive fraud investigations conducted by private detectives, this finding did not automatically result in the exclusion of illegally obtained evidence. ${ }^{99}$ Article 6 of the ECHR does not entail specific rules on the admissibility and assessment of pieces of evidence and the Court is not required to correct any error of fact or law made by national courts. Considering its nature as an international human rights court, the ECtHR focuses on the defense rights of the applicant and the importance of the evidence in question. ${ }^{100}$ If the applicant was given an opportunity to challenge the authenticity of the evidence and to oppose its use in the national proceedings, it is unlikely that the ECtHR will consider that the right to a fair trial (Article $6 \mathrm{ECHR}$ ) has been infringed. A similar position has been visible in civil cases in the United Kingdom where the admissibility of evidence obtained by private investigators was unsuccessfully challenged on the grounds of the breach of human rights. ${ }^{101}$ English courts have made a proportionality assessment in this type of cases, weighing the rights of the individual against

96 See H.E. Bröring, 'De Bestuurlijke Boete' [The Administrative Fine] (Alphen aan den Rijn: Kluwer, 2005) 159-160.

97 See C. Meerts, 'Over pragmatisme en strategie' [On Pragmatism and Strategy], Tijdschrift voor Criminologie (2014(4)) [in Dutch]; Burkoff (n 65) 628.

98 See also J.Herveg and J-M. van Gysehem, 'La protection des données à caractère personnel en droit européen - Chronique de jurisprudence (2018)', Journal Européen des Droits de l'Homme 1 (2019) 33-88, 21.

99 Vukota-Bojić v. Switzerland, no. 61838/10, § 93, ECHR 2016: 'It is not [...] the role of the Court to determine, as a matter of principle, whether particular types of evidence - for example, evidence obtained unlawfully in terms of domestic law - may be admissible. The question which must be answered is whether the proceedings as a whole, including the way in which the evidence was obtained, were fair.'

100 See I. Langford, 'Fair Trial: The History of an Idea', Journal of Human Rights 8(1) (2009) $37-5^{2}$.

101 Ian Trumper, 'Accounts and Management Fraud', in: A. Doig (ed.), Fraud: The Counter Fraud Practitioner's Handbook (London: Routledge, 2012) 85-105, referring in particular to Jones v. Warwick University [2003] 1 WRL 954 [2003] EWCA Civ 151 where the judge found 
the harm to others within the framework of justice.102 In the Netherlands, Dutch administrative courts have reached different decisions, determining the exclusion of evidence on the grounds of the violation of human rights, namely the right to a fair trial. ${ }^{103}$

Although we understand the need to guarantee the economy of judicial proceedings and the possibility to admit illegally obtained evidence based on a proportionality assessment, we contend that the circumstances under which evidence has been collected, should be taken into account if they cast doubt on its reliability and accuracy. This will be the case when private actors have strong commercial incentives to find fraud and the public oversight of private investigative actions is limited. In these cases, courts should be extra vigilant as potential interferences with the obtained material and the violation of the individuals' guarantees.

\subsubsection{Legitimacy Deficit and Good Administration}

Several critics of privatization have argued that public officials should be preferred to private contractors not only because they can perform certain tasks better but also because their identity as public agents has an intrinsic value which imbues them with enhanced political legitimacy. ${ }^{104}$ The outsourcing of public services is nevertheless often justified by the demand for enhanced expertise and efficiency which confers legitimacy to private actors. ${ }^{105}$ When applying this criterion to social welfare fraud investigations, it can be questioned whether this field requires enhanced expertise. ${ }^{106}$ Rather, social welfare investigations aim to verify simple facts: does the beneficiary live alone or does this individual cohabitate? Is the income of the beneficiary correct? Is the beneficiary living at her registered address? These factual investigations are timeconsuming and can be easily optimized with the assistance of digital research

that the method used to obtain evidence was unlawful but the conduct was not so outrageous as to exclude the evidence and affect the fairness of the trial.

102 Ian Trumper, 'Accounts and Management Fraud', in: A. Doig (ed.), Fraud: The Counter Fraud Practitioner's Handbook (London: Routledge, 2012) 85-105.

103 Centrale Raad van Beroep, 16 September 2014, ECLI:NL:CRVB:2014:2947.

104 A. Harel and A. Porat, 'Commensurability and Agency: Two Yet-to-Be-Met Challenges for Law and Economics', Cornell Law Review 96(4) (2011) 749-787 at 769, 777.

105 See Donnelly (n 9) 342; K. Yeung, 'Privatizing Competition Regulation', Oxford Journal of Legal Studies 18 (1998) 581-615.

106 A. Outhuijse, 'De introductie van private partijen in het bouwtoezicht. Waar moeten we aan denken?' [The introduction of private actors in the supervision of the construction sector], $\mathrm{TO}_{3}$ (2013) 79 [in Dutch]. 
techniques that can select potential candidates for formal investigations. ${ }^{107}$ This selection phase demands advanced digital skills and equipment which may or may not always be present in public bodies. ${ }^{108}$

The employment of private actors can still raise concerns regarding a number of values and principles of administrative law such as openness, transparency, impartiality, rationality, and accessibility of administrative decisions. ${ }^{109}$ Furthermore, the existence of a legal basis for outsourcing does not take away the fact that private detectives are driven by private interests rather than the pursuit of the public interest. ${ }^{110}$ We expect this misalignment of interests to occur in particular when the remuneration of private detectives is dependent on how much fraud they are able to detect or private companies are able to draw economic benefits from the data they collected in the context of investigations. ${ }^{111}$ Multiple questions will arise then in this context: Will private detectives also be willing to collect exculpatory evidence? Will they comply with rules on data-protection, even when this is detrimental to the successful of their risk-assessments?

\subsection{Private Actors as Providers of Data-Driven Enforcement Systems}

The use of automated systems is currently pervasive both in the public and private sectors. ${ }^{12}$ The involvement of private technology companies ranges from those providing specialized fraud detection services to the provision of software. ${ }^{113}$ However, technology companies are increasingly involved in public decision-making as they design integrated solutions that are used for

107 Predictive analytics is also being used in the United States for example to detect cases of illegal conversion of houses, building inspections for public safety hazards, fighting prescription drug epidemic: See A. Howard, 'Predictive Data Analytics Is Saving Lives and Taxpayer Dollars in New York City'. O'Reilly 2012, June 26. Retrieved 19 December 2019, https://www.oreilly.com/ideas/predictive-data-analytics-big-data-nyc.

108 See, generally, on the interaction between public and private actors: O. Butler, 'Obligations Imposed on Private Parties by the GDPR and UK Data Protection Law: Blurring the Public-Private Divide', European Public Law 24(3) (2018) 555-572.

109 Freeman (n 16) 814, 818, 819.

$110 \quad$ Bowen Matthew (n 67) 338.

111 See, generally, J-J. Laffont and J. Tirole, 'Privatization and Incentives', Journal of Law, Economics, and Organisation 7 (special issue) (1991) 84-105; N. Davidson, 'Contracts in the Privatization of Social Welfare: The Case of Housing', Yale Law \& Policy Review 24(2) (2006) (Davidson) 263-316.

112 See, for instance, AI Now Institute. 'Litigating Algorithms: Challenging Government Use of Algorithmic Decision Systems'. 2018. Retrieved 19 December 2019, https://ainowinstitute.org/litigatingalgorithms.pdf [https://perma.cc/KZ52-PZAH], p. 5 .

113 Human Rights Watch, 'May 2019 Submission to the UN Special Rapporteur on Extreme Poverty \&Human Rights Regarding His Thematic Report on Digital Technology, Social 
government data and services. ${ }^{114}$ It is in this context that we observe a novel form of privatization of welfare fraud investigations in the United Kingdom, the United States, the Netherlands, and Switzerland. In the last five years, the media has discussed the use of automated systems in social welfare fraud prevention. ${ }^{115}$ Public bodies use for example data sharing and data matching systems that seek to break down longstanding data-silos that may be preventing not only a joined approach to public services but also the detection of inconsistent information and thus fraud. ${ }^{116}$ However, these systems are not always developed by public bodies. Instead, they are acquired from Big Tech companies such as IвM. To illustrate, the IвM InfoSphere Master Data Management has been employed in Camden (United Kingdom) to develop a residents' index that links data sources from across Camden and uses probabilistic matching techniques for identity verification and fraud detection. ${ }^{117}$ This has been used to detect school admission fraud in situations where individuals falsely claim to live close to a popular school so that their children can get a place. The index developed by Iвм checks all the addresses that a family has given to each of their services and establishes whether there are discrepancies. If the system

Protection \& Human Rights'. Retrieved 29 July 2019, https://www.ohchr.org/EN/pages/ home.aspx (Human Rights Watch).

114 See J. Hudson, 'Digitising the Structures of Government: The UK's Information Age Government Agenda', Policy and Polity 30(4) (2002) 513-531.

115 Data Justice Lab, 2018. 'Digital Technologies and the Welfare State'. September 14. Retrieved 19 December 2019, https://www.ohchr.org/Documents/Issues/Epoverty/UnitedKingdom/2018/Academics/DataJusticeLabCardiffUniversity.pdf (Data Justice Lab).

116 Department for Work and Pensions, 2019. 'Individual Electoral Registration-Confirmation DWP Data Matching Methodology'. Retrieved 19 December 2019. https://www.gov.uk/ government/uploads/system/uploads/attachment_data/file/262931/ERTP_ CONFIRMATION_DATA_MATCHING_METHODOLOGY.pdf. The largest database in the Netherlands is SyRi (a Risk Indication System), which is managed by the Minister of Social Affairs and combines data from various local and federal public bodies to design risk profiles based on algorithms to combat social welfare fraud. See P. Olsthoorn, 'Big Data voor fraudebestrijding' [Big Data for Fraud Prevention], Working Paper WRR no. 21. Retrieved 15 July 2019, https://www.wrr.nl/publicaties/working-papers/ 2016/04/28/big-data-voor-fraudebestrijding. See M. Hijink, 2018. 'Hoe controleert de gemeente of jij fraudeert?' [How Does Local Government Check if You Are Cheating], NRC, April 6. Retrieved 19 December 2019, https://www.nrc.nl/nieuws/2018/04/o6/hoecontroleert-de-gemeente-of-jij-fraudeert-a1598455. The Netherlands Scientific Council for Government Policy published a policy brief, in which it highlights the use of Big Data analytics in security practice: See D. Broeders, E. Schrijvers, and E. Hirsch Ballin, 'Big Data and Security Policies: Serving Security, Protecting Freedom'. 2017. Retrieved 15 July 2019, https://english.wrr.nl/publications/policy-briefs/2017/01/31/bigdata-and-security-policies-serving-security-protecting-freedom.

Data Justice Lab (n 115). 
raises a red flag, an audit team can investigate further. Similar services are provided to municipalities in the Netherlands by Totta Data Lab and Ynformed. As mentioned earlier, private detective companies are also allowed to employ automated systems when monitoring welfare recipients in Switzerland. On the other side of the Atlantic, the California state legislature amended the Welfare and Institutions Code in 2017 to replace fingerprint imaging with an "automated, nonbiometric" method for verifying the identity of applicants to the CalWORKs program, which provides cash assistance to needy families. Public authorities also relied here on a private company (Pondera solutions) to conduct a pilot of a cloud-based identity verification system (Knowledge Based Authentication System). This pilot raised several legal concerns as the private company refused to explain how the data was analyzed, making it difficult for the broader public to assess the accuracy of the system. ${ }^{118}$ In addition, the system required the collection of highly sensitive data. ${ }^{119}$

Fraud investigations are not yet fully automated and it is not the aim of this section to explain in detail exactly what specific technology is being used. Rather, our focus lies in the legal issues raised by the delegation of public tasks (fraud inspections) to private companies through the contracting of technology. In May 2019, Human Rights Watch submitted a report to the UN Special Rapporteur on Extreme Poverty \& Human Rights explaining how states throughout the world were delegating key welfare functions (including determination of eligibility and benefits levels and fraud investigations) to automated decision-making systems. ${ }^{120}$ In the cases described in the report, citizens targeted by these systems were not tech-savvy, integrated underrepresented groups, and were directly and indirectly stigmatized and discriminated. Moreover, the automated systems involved an opaque analysis of large datasets containing a wide range of sensitive data. ${ }^{121}$

At the resemblance of the two previous forms of involving private actors in welfare fraud investigations, the use of digital technology developed by private companies changes the way in which welfare fraud investigations are conducted in several ways. First, it is not always clear what data these technologies rely upon to establish the probability that someone will commit fraud. Fraud investigators will primarily consider past statistics, for example, data stating that a certain group of citizens (e.g., pensioners) is less likely to commit

118 As a consequence, the California Department of Social Services decided not to implement this automated system.

119 Human Rights Watch (n 113).

120 Ibid.

121 Ibid. 
fraud. ${ }^{122}$ However, it may be difficult to obtain specific information for example, on the weight of certain data in the calculation of a risk score. ${ }^{123}$ The process by which data systems are developed and then implemented by investigators may not always be accessible to the public. ${ }^{124}$ While public authorities could hypothetically work on improving the transparency of these systems by requesting contractors to disclose proprietary information, this is not always possible in practice. Moreover, the opacity of these digital systems is reinforced by the absence of information regarding the oversight mechanisms in place. ${ }^{125}$ This opacity is particularly serious when it is directly or indirectly used by fraud teams to make decisions that affect individuals' ability to receive welfare benefits. Therefore, the existence of public-private partnerships makes it difficult for citizens to scrutinize automated systems, reduces the accountability of public authorities, and the protection of citizens against their human rights impacts. $^{126}$

Second, the use of complex data-driven systems is susceptible of violating fundamental rights. The right to non-discrimination (Article 14 ECHR, Article 1 of the Additional Protocol), the right to private and family life (Article 8 ECHR) including personal data can be violated by automated systems in multiple ways. Risk assessments often result in profiling and thus the stigmatization of certain groups and minorities who are thought to present a higher risk of fraudulent behavior. ${ }^{127}$ Also, automated assessments are not always focused on

122 Department for Work and Pensions, 'The Results of the Area Benefit Review and the Quality Support Team from April 2000 to March 2001' (London, Analytical Services Division and National Statistics, 2002).

and the Quality Support Team from April to March, London: Analytical Ser-vices Division and National Statistics, DWP.

123 Many of these concerns were raised in State v Loomis 881 NW2d 749 (Wis 2016) 754 (United States). See, for a broader discussion of the opacity of these systems, F. Pasquale, The Black Box Society: The Secret Algorithms that Control Money and Information (Cambridge, Mass: Harvard University Press, 2015); H-W. Liu, Ching-Fu-Lin, and Y-J. Chen, 'Beyond State v Loomis: Artificial Intelligence, Government Algorithmization and Accountability', International Journal of Law and Information Technology 27(2) (2019) 122-141.

124 See S.K. Katyal, 'The Paradox of Source Code Secrecy', Cornell Law Review 104(5) (2019) 1183-1280.

125 Data Justice Lab ( $\mathrm{n} 115)$.

126 D. Reisman, J. Schultz, K. Crawford, and M. Whittaker. 'Algorithmic Impact Assessments: A Practical Framework for Public Agency Accountability'. AI Now 2018, April 13. Retrieved 19 December 2019, https://ainowinstitute.org/aiareport2018.pdf (Reisman and others).

127 Lord Grabiner, The Informal Economy (London: HM Treasury-government publication, 2002) 14; P. Dornan, and J. Hudson, 'Welfare Governance in the Surveillance Society: A Positive-Realistic Cybercriticalist View', Social Policy and Administration 37(5) (2003) 468-482 (Dornan and Hudson) at 474. 
establishing behavior (i.e., whether an individual abuse the system) but on predicting it. ${ }^{128}$ This means that selected citizens will be closely watched because their personal characteristics (e.g., age group, gender, ethnicity) place them in a category of people (e.g., middle-age women) that is more likely to commit fraud. On the grounds of these probabilistic models and historical data, these individuals will then be more intensely scrutinized and often marginalized under the guise of objective evidence-based analyses. ${ }^{129}$ Probabilistic models that act on group characteristics rather than a qualitative assessment of an individual's characteristics may contravene the Human Rights Act (in the United Kingdom), the EU Charter of Fundamental Rights, and the ECHR. ${ }^{130}$ In addition, predictive systems reinforce stereotypes, the belief that averages are more important than morality, and the sense of justice that requires evidence of wrongdoing rather than the probability thereof. ${ }^{131}$

Although governments claim that they gather anonymous data to build automated systems, the risk of re-identification of data by private companies is real. The data in public services, particularly in the field of social welfare, includes very sensitive information which if re-identified, can have important consequences and result in continued stigmatization. ${ }^{132}$ Digital trails left during a fraud investigation may determine someone's life chances to a significant extent (for example, if there is online information on the suspicion that an individual committed fraud, her reputation or credit score may be seriously affected). ${ }^{133}$

128 R. Peeters and M. Schuilenberg, 'Machine Justice: Governing Security through the Bureaucracy of Algorithms', Information Polity 23(3) (2018) 267-280.

129 S.J. Prins and A. Reich, 'Can we Avoid Reductionism in Risk Reduction?', Theoretical Criminology 22(2) (2018) 258-278 at 259; M. Hamilton, 'The Biased Algorithm: Evidence of Disparate Impact on Hispanics', American Criminal Law Review 56(4) (2019) 1553-1578 at 1559.

130 Dornan and Hudson (n 128) 473.

131 S. Barocas and A.D. Selbst, 'Big Data's Disparate Impact', California Law Review 104(3) (2016) 671-732. See also, discussing the morality implications of predictive models, F. Schauer, Profiles, Probabilities, and Stereotypes (Cambridge, Mass: Harvard University Press, 2006).

132 S. Wachter, 'Normative Challenges of Identification in the Internet of Things: Privacy, Profiling, Discrimination, and the GDPR', Computer Law \& Security Review 34(3) (2018) 436-449.

133 This concern has been raised in the immigration context, as there are rumors that Palantir is providing data collected for other purposes that can be later used to detect undocumented workers during raids: See E. Anzilotti. 'Emails Show that ICE Uses Palantir Technology to Detain Undocumented Immigrants: wnYC Report'. Fast Company 2019, July 6. Retrieved 5 August 2019, https://www.fastcompany.com/90377603/ ice-uses-palantir-tech-to-detain-immigrants-wnyc-report. 
Third, the outsourcing of public tasks may result in the expansion or reduction of discretionary powers beyond the original intent of the legislator. ${ }^{134} \mathrm{Ex}-$ isting social welfare legislation was drafted with human decision-makers in mind. ${ }^{135}$ In the context of automated systems or risk assessments that support decision-making, we will often see or fear different interpretations of the law. The interpretation of vague and indeterminate terms will be primarily focused on past data analytics (e.g., if someone has committed fraud once or belongs to an ethnic group that has abused the system in the past, the system may flag this individual as a potential abuser). Although many of these objections are applicable to both public and private automated systems, the involvement of private companies in welfare investigations enhances the risk of unfair, disproportionate and discriminatory treatment due to the misalignment of interests and values between public and private parties.

A Normative Framework for the Privatization of Public Enforcement

In this section, we offer a normative framework that seeks to reframe the intervention of private actors so as to ensure that welfare fraud investigations are fair, transparent, non-discriminatory, and conducted in the strict pursuit of the public interest.

\subsection{Limited Outsourcing of Inherently Governmental Tasks}

As a first normative limit to the privatization of public enforcement, we suggest limiting the outsourcing of certain public tasks to private actors, particularly the task of investigating welfare fraud (including the surveillance of individuals). We argue that the detection and sanctioning of fraud are inherently governmental tasks because they affect the exercise of fundamental rights that can be more adequately protected by public authorities than private actors. "Inherently governmental tasks" have been traditionally presented in the literature in civil and common law countries as tasks that should be reserved to

134 See A. Le Sueur, 'Robot Government: Automated Decision-Making and its Implications', in: A. Horne and A. Le Sueur (eds), Parliament: Legislation and Accountability (Oxford and Portland: Hart Publishing, 2016) Part 2(9.).

135 M. Hildebrandt, 'Law as Information in the Era of Data-Driven Agency', Modern Law Review 79(1) (2016) 1-30. 
public bodies and that, as such, cannot be outsourced or require a very strict and detailed legal basis for the outsourcing of specific tasks. ${ }^{136}$

The concept of 'inherently governmental tasks' is closely connected to the idea that some public tasks are particularly designed for the benefit of the whole collectivity."137 This concept has been defined in the United States as "a function that it is so intimately related to the public interest as to require performance by Federal Government employees." 138 Under the "nature of the function" test, a task will be regarded as "inherently governmental" if it involves "exercising sovereign power," for example, that of depriving someone of liberty in the name of public safety. ${ }^{139}$ Our position draws on the positon adopted in 2014 by the Dutch High Court for Social Affairs. In a case involving private detectives, the Court stated that while the Dutch Social Welfare Act offered room for the delegation of administrative tasks in general, it also stated that law enforcement and fraud investigations constituted a core task of the public administration. As such, this task could not be delegated without a more specific legal provision. ${ }^{140}$

The delimitation of "inherently governmental tasks" evokes the traditional debate on the divide between public and private spheres which has been

136 See, for instance, J.R. Luckey, V. Bailey Grasso, and K.M. Manuel, 'Inherently Governmental Functions and Department of Defense Operations: Background, Issues, and Options for Congress'. Congressional Research Service 2010, February 1. Retrieved 19 December 2019, https://www.fas.org/sgp/crs/natsec/R40641.pdf - discussing the statutory and policy definitions of "inherently governmental function"; F. van Ommeren and G. Jurgens, 'The Public-Private Divide in English and Dutch Law: A Multifunctional and ContextDependent Divide', Cambridge Law Journal 71(1) (2012) (van Ommeren and Jurgens) 172199. See, generally, P.R. Verkuil, Outsourcing Sovereignty: Why Privatization of Government Functions Threatens Democracy and What We Can Do about it (New York: Cambridge University Press, 2007); D. Oliver, Common Values and the Public-Private Divide (Cambridge: Cambridge University Press, 1999).

137 C. Harlow, "Public' and 'Private' Law: Definition without Distinction', Modern Law Review 43(3) (1980) 241-265; K. Chan, The Public-Private Nature of Charity Law (London: Bloomsbury, 2016) 181.

138 M. Tirard, 'Privatization and Public Law Values: A View from France', Indiana Journal of Global Studies15 (2008) 285-304 at 292. See, however, for the United Kingdom, T. Prosser, 'Social Limits to Privatization', Brooklyn Journal of International Law 21(1) (1998) 213-242 at 218 , analyzing the limits of privatization from a comparative perspective and stating that the "United Kingdom experience shows quite clearly that there is no core of governmental activity which cannot be privatized.". A functional approach to outsourcing was applied in the United Kingdom in R v. Panel on Take-Overs and Mergers, ex p Datafin [1987] Q.B. 815 (CA) 847 .

139 O'Carroll (n 16).

140 Centrale Raad van Beroep, 16 September 2014, ECLI:NL:CRVB:2014:2947. 
particularly visible in civil law countries. ${ }^{141}$ Although this debate has been dismissed as obsolete, it still offers a framework and a vocabulary that helps us distinguish between tasks to which public law principles apply and governmental tasks that cannot be outsourced. ${ }^{142}$ The public law-private law divide has been inspired by the ideological perception that there are certain missions and values of public law that should not be attributed to other entities since they are inherent to the pursuit of the common good, not private advantage. ${ }^{143}$ The definition of the limits of the public realm is highly dependent on time, place, culture, reigning interests, and needs. ${ }^{144}$ It is thus a normative question which has changed throughout time and is historically contingent. ${ }^{145}$

The provision of social assistance itself was traditionally in the hands of private actors, charities, and churches. In the nineteenth century, states relied on private charities to provide social assistance to the needy. ${ }^{146}$ However, as private benevolent societies became unable to meet the increasing needs of expanding populations, in particular after the Great Depression, the Welfare State emerged. In modern days, most Western countries have included social welfare in the imperium of public law. Although social security and public

141 van Ommeren and Jurgens ( $\mathrm{n}$ 137); L. van den Berge, 'Rethinking the Public-Private Divide in the Age of Governmentality and Network Governance: A Comparative Approach of French, English and Dutch Law', European Journal of Comparative Law and Governance 5(2) (2018) 119-143.

142 C.M. Flood and B. Thomas, 'Blurring of the Public/Private Divide: The Canadian Chapter', European Journal of Health Law 17(3) (2010) 257-278; D. Kennedy, 'The Stages of the Decline of the Public/Private Distinction', University of Pennsylvania Law Review 130(6) (1982) 1349-1357.

143 J.S. Bell, 'Comparative Administrative Law', in: M Reimann and R Zimmermann (eds.), Oxford Handbook of Comparative Law (2006) 1260-1286 at 1262. See also H-W. Micklitz, 'The Public/Private Divide', in: L Poiares Maduro, K. Tuori, and S. Sankari (eds), Translational Law: Rethinking European Law and Legal Thinking (Cambridge: Cambridge University Press, 2014) 271-306.

144 See, for an analysis of the definition of "public interest", J. Johnston. 'Whose Interests? Why Defining the 'Public Interest' Is Such A Challenge'. The Conversation 2017, September 21. Retrieved 19 December 2019, https://theconversation.com/whose-interests-why-defining-the-public-interest-is-such-a-challenge-84278; S.M. King, B.S. Chilton, and G.E. Roberts, 'Reflections on Defining the Public Interest', Administration \& Society 41(8) (2010) 954-978.

145 B.P. Vermeulen, 'De publieke taak: een veel-zijdig begrip' [The Governmental Function: A Multi-faceted Concept], in: J.W. Sap, B.P. Vermeulen, and C.M. Zoethout (eds), De Publieke Taak (2003) 13, 21 [in Dutch].

146 M. Estrin Gilman, 'Legal Accountability in an Era of Privatized Welfare', California Law Review 89(3) (2001) 569-642, (Estrin Gilman) 583-584. See, generally, E.P. Hennock, The Origin of the Welfare State in England and Germany, 1850-1914 (Cambridge: Cambridge University Press, 2007); A. Briggs, 'The Welfare State in Historical Perspective', European Journal of Sociology 2(2) (1961) 221-258. 
assistance have been for decades at the heart of the welfare state, ${ }^{147}$ it can be argued that the provision of assistance and the control of eligibility and the enforcement of social security laws have different natures. The former has become increasingly instrumental and thus susceptible of being delegated to private actors. ${ }^{148}$ The latter has remained in the hands of public authorities as it involves sanctions. It would be difficult to argue that every aspect of social welfare should be kept in public hands. Indeed, the existence of a right to certain public services does not mean that there is a constitutional anti-privatization framework that draws the borders for contracting with private entities for the provision of public services. ${ }^{149}$ Instead, welfare pluralism has become part of the larger debate on how to reduce the costs of the welfare state. ${ }^{150}$ Nevertheless, the control of eligibility and law enforcement are decisive to the exercise of the right to social security. They relate directly to the provision of public assistance which guarantees the survival, education, and basic living conditions of citizens.

Allowing private citizens to monitor welfare recipients or encouraging citizens to denunciate neighbors and family members further stigmatizes social welfare and it opens the door to multiple forms of abuse. Moreover, the outsourcing of public enforcement, particularly when primarily guided by opaque and biased data-driven systems, is susceptible of interfering with citizens' fundamental rights. ${ }^{151}$ Automated systems acquired from private companies should therefore be developed according to ethical standards and be aligned with the same public values and rules that characterize public law enforcement. As the ECtHR has underlined, public authorities should not evade their obligations by outsourcing tasks to private parties, the standards and underlying values of law enforcement must be the same regardless of whether the enforcement is performed directly by a public authority or a private party with

147 C.A. Reich, 'Midnight Welfare Search and the Social Security Act', Yale Law Journal 72(7) (1962) $1347-1360$ at 1359 .

148 A.C. Aman Jr., 'Globalization and the Privatization of Welfare Administration in Indiana', Indiana Journal of Global Legal Studies 2o(1) (2013) 377-424; A. Eleveld and O. van Vliet, 'The Dutch Welfare State: Recent Reforms in Social Security and Labour Law', Diritto Pubblico Comparato ed Europeo 4 (2014) 1371-1399.

149 J.M. Beermann, 'Privatization and Political Accountability', Fordham Urban Law Journal 28(5) (2001) 1507-1557, 1510; A. Volokh, 'Privatization and the Elusive EmployeeContractor Distinction', U.C. Davis Law Review 46(1) (2012) 133-208 at 138.

150 P. van Aerschot, 'The Privatization of Social Services', in: M. Koskenniemi (ed.), The Finnish Yearbook of International Law: Volume VIII (1997) (The Hague: Kluwer Law International, 1999) 457-472.

151 See M. Hu, 'Algorithmic Jim Crow', Fordham Law Review 86(2) (2018) 633-696. 
delegated powers. ${ }^{152}$ Automated systems should be for example audited and controlled so that public authorities can assess according to what values and categories welfare recipients are being classified. ${ }^{153}$ Their private character and the proprietary nature of their software cannot be evoked as an excuse to apply a different legal regime. Indeed, the legitimacy of privatization and outsourcing depends on the application of the same rules to public and private enforcers, including in the context of data collection and processing. ${ }^{154}$

Finally, there is limited evidence that the privatization and optimization of social welfare enforcement can have beneficial effects decreasing poverty and the dependency of individuals on assistance. ${ }^{155}$ Instead, the privatization of social welfare appears to affect directly the nature of the state-citizen relationship converting it into a contractual relationship with reduced levels of accountability, legitimacy, and transparency. ${ }^{156}$

\subsection{Accountability Mechanisms}

In the digital age, enhanced transparency has been often viewed as the response to the use of automated systems. ${ }^{157}$ Data-driven systems and other opaque strategies developed by private bodies should benefit not only from enhanced transparency but also clear accountability mechanisms that allow citizens to understand how a decision was made. ${ }^{158}$

152 Van Vondel $v$ The Netherlands, no. 38258/03, § 49, ECHR 2007.

153 T. Zarsky, 'The Trouble with Algorithmic Decisions: An Analytic Road Map to Examine Efficiency and Fairness in Automated and Opaque Decision Making', Science Technology and Human Values 41(1) (2016) 118-132. See also D. Citron and F. Pasquale, 'The Scored Society: Due process for automated predictions', Washington Law Review 89(1) (2014) 1-33; B.A. Williams, C.F. Brooks, and Y. Shmargad, 'How Algorithms Discriminate Based on Data They Lack: Challenges, Solutions, and Policy Implications', Journal of Information Policy 8 (2018) 78-115.

154 See N. Purtova, 'Between the GDPR and the Police Directive: Navigating through the Maze of Information Sharing in Public-Private Partnerships', International Data Privacy Law $8(1)(2018) 5^{2-68 .}$

155 G. Craig, 'The Privatization of Human Misery', Critical Social Policy 18(54) (1998) 51-76. The literature has instead suggested that the privatization of different sectors may be detrimental to poor consumers and citizens: See M. Drakeford, 'The Poverty of Privatization: Poorest Customers of the Privatized Gas, Water and Electricity Industries', Critical Social Policy 17(51) (1997) 115-132.

156 P.M. Larkin, 'The Legislative Arrival and Future of Workfare: The Welfare Reform Act 2009', Journal of Social Security Law 18(1) (2011) 11, 28.

157 R. Brauneis and E.P. Goodman, 'Algorithmic Transparency for the Smart City', Yale Journal of Law and Technology 20 (2018) 103-176.

158 See M. Perel and N. Elkin-Koren, 'Black Box Tinkering: Beyond Disclosure in Algorithmic Enforcement', Florida Law Review 69 (2017) 181-221. 
Thus far, Dutch public bodies at the central level have sought to legitimize contracts with private parties by disclosing information regarding the existence of a digital investigation phase. They have also informed the Parliament and the public that they were indeed building "data warehouses" about citizens and used various queries and risk profiles to detect high risks of fraud..$^{159}$ In the United States, there is a growing debate on the introduction of Algorithmic Impact Assessments. ${ }^{160}$ These assessments aim to reduce the opacity of automated systems and would require each public authority to publicly list and describe all existing and proposed automated decision systems, including their purpose, reach, and potential impacts on identifiable groups or individuals. These systems would allow the public to review and audit the algorithms used by agencies. The effectiveness of these algorithmic impact assessments depends nonetheless on an increase in the internal expertise and capacity of public authorities to evaluate the fairness and risk of discrimination of systems they procure. ${ }^{161}$

Accountability mechanisms should also include information on the supervision of private companies, the responsibility taken for potential mistakes, and an assessment of the human rights impacts of employed automated systems. The need to accept this responsibility should be proportionate to the degree of involvement of public bodies in the process and the benefit they could potentially draw from their contracts with private companies. ${ }^{162}$

An important question that arises is whether a system of enhanced accountability can address the legitimacy deficit of private actors and guarantee that the outsourcing of public tasks does not have a negative impact on the public interest. ${ }^{163}$ As Jody Freeman has explained, privatization does not need to be accompanied by a reduction in accountability. Instead, public bodies should seek to "publicize" certain services by imposing public values and rules on private providers, particularly when these actors will have to exercise discretion and serve vulnerable groups. ${ }^{164}$ This aspect is particularly important in

159 Also in the enforcement of student allowances the parliament was informed about the private investigations and risk-profiling, see parliamentary papers 2010/11, 32770.

16o Reisman and others (n 126).

161 D. McCabe. 'Lawmakers Are Trying to Understand How Tech Giants' Algorithms Work'. Axios 2017, November 29. Retrieved 1 August 2019, https://www.axios.com/lawmakersare-trying-to-understand-how-tech-giants-algorithms-work-1513307255-b410gefc9566-4e69-8922-f37dge829fif.html.

162 F. W. Bleichrodt, Over burgers en opsporing [On Citizens and Crime Detection] (2000) p. 16 [in Dutch].

163 See, for instance, Davidson (n 111); J. D. Michaels (n 53).

164 J. Freeman, 'Extending Public Law Norms Through Privatization', Harvard Law Review $116(5)(2003) 1285^{-135^{2}}$ at 1345 . 
the context of profiling. Although at the time of writing there is limited case law about profiling in general, Dutch courts have been critical as regards the use of ethnical profiling regardless of whether these profiles are developed by public and private actors and have declared various profiling practices unconstitutional as they breach the principle of equality and the prohibition of non-discrimination. ${ }^{165}$

Enhanced accountability can also be achieved through clearer contractual terms and ensuring that private investigators are bound by stricter legal constraints. Limiting the discretion of private actors gives the government greater influence and reduces potential ambiguities as well as the mismatch between private and public interests. In addition, as Nestor Davidson explains, clear contractual arrangements in social welfare also give "a clear metric for translating public goals into a discernable framework of delegation, as well as effective means to ensure that those goals are being met."166

The general regulation of the involvement of private actors in the administration of public tasks varies greatly between highly regulated systems in certain continental European countries (strict training hours, equipment) and minimal and experimental standards on voucher systems and eligibility control imposed by state or provincial regulations in the United States. ${ }^{167}$ Nevertheless, accountability for the involvement of private actors in welfare fraud investigations should mean that public authorities do not employ informants, private detectives, and automated systems without adequate supervision, instructions, and a clear framework. This brings us to the last mechanism of enhancing accountability: the extension of public law obligations (administrative law and human rights) to private actors in addition to contract and tort law. ${ }^{168}$ In the United Kingdom and the United States, there has been significant resistance towards the incorporation of general public law or human rights

165 For example, the Dutch public body responsible for a number of tasks within the Ministry of Education (DUO) including student loans and student house allowances, has created risk profiles (e.g. the distance between the parents' address and the registered address. Various other social welfare institutions profiled on the base of property (especially in Turkey, because of the sound registration of housing property), on ethnicity, country of origin or descent (especially Morocco), or age (especially citizens older than 55 due to their limited employability). See, for example, Centrale Raad voor Beroep (CRvB) 14 April 2015, ECLI:NL:CRVB:2015:1228; CRvB 8 September 2015, ECLI:NL:CRVB:2015:3249; CRvB 21 November 2017, ECLI:NL:CRVB:2017:4068. Ethnical profiling has been allowed in CRvB 1 October 2018, ECLI:NL:CRVB:2018:2912.

166 Davidson (n 111) 277 .

167 H. Freedman, M.R. Mannix, M. Cohan, and R. Scharf, 'Uncharted Terrain: The Intersection of Privatization and Welfare', Clearinghouse Review 35(9/10) (2002) 557-572.

168 Donnelly (n 9) 350. 
obligations in contracts. ${ }^{169}$ Instead, it is up to public bodies to draft contractual specifications that ensure adequate monitoring of contractors. Contrary to Dutch cases analyzed earlier in this article, U.K. and U.S. Courts have also proven to be reluctant to extend public law to private contractors. ${ }^{170}$

\subsection{Proportionate Enforcement}

Welfare fraud investigations involving intrusive surveillance conducted by public or private actors are required to be in conformity with clear and specific rules as well as with the principle of proportionality. ${ }^{171}$ As explained earlier, surveillance is in "accordance with the law" when investigation powers have "some basis in domestic law (as opposed to a practice which does not have a specific legal basis)."172 Compliance with the principle of proportionality requires a more complex assessment. This was underlined in the ECtHR decision Big Brother and others v. the United Kingdom which held that the ability to order disproportionate forms of mass surveillance on citizens was a violation of the rights to privacy and freedom of expression. ${ }^{173}$ Public institutions are often confronted with the accusation that it is not proportionate to employ surveillance technologies that gather huge amounts of data but that only deliver a small number of successful cases. ${ }^{174}$ This is true not only in the case of surveillance for the protection of national security but also in the context of welfare investigations (for example, in the pending Dutch case of SyRi).

The aim behind welfare investigations is clearly a legitimate one: to secure the sustainability of the welfare system. Nevertheless, the methods used to enforce welfare conditionality must not exceed the necessary and adequate minimum that is required to detect fraud. ${ }^{175}$ Considering that outsourcing enforcement tasks to private actors exacerbates the risk of violation of fundamental rights, public institutions should make a double proportionality assessment: first, is it necessary and adequate to outsource welfare investigations to

$169 \operatorname{Ibid} 381$.

170 See the leading case, YL v. Birmingham City Council, [2007] EwCA Civ 26, (2008) Q.B. 1. For a thorough analysis of this issue see Donnelly (n 9).

171 J. Milaj, 'Privacy, surveillance, and the proportionality principle: The need for a method of assessing privacy implications of technologies used for surveillance,' International Review of Law, Computers \& Technology 30(6) (2016) 115-130.

172 Heglas v. the Czech Republic no. 5935/02, § 74, 1 March 2007.

173 Big Brother Watch and others v. United Kingdom (Applications nos. 58170/13, 62322/14 and 24960/15) [2018] ECHR 722, § 352-388.

174 M. Crayford and W. Pieters, 'The Effectiveness of Surveillance Technology: What Intelligence Officers Are Saying', The Information Society 34(2) (2018) 88-103.

175 See generally on this topic B. Watts and S. Fitzpatrick, Welfare Conditionality (London: Routledge, 2018). 
private actors and what are the risks of doing so? Second, the need to use additional and undercover means to gather evidence should be balanced against the right to privacy of welfare recipients. ${ }^{176}$ This right should be here understood as comprehending the right not to be subject to intrusive investigations for small mistakes (e.g., failure to disclose limited additional income) and not to reuse data that was not collected with the original purpose of surveillance. ${ }^{177}$ For example, Section 1 (2) of the Social Security Fraud Act 2001 (United Kingdom) provides that an authorized officer can request information from private and public sector organizations regarding individuals, provided there are "reasonable grounds" for believing that the claimant or a family member is committing or intends to commit an offence. Although this disposition is complemented by a statutory code of practice, this piece of legislation has raised questions regarding the data protection of welfare recipients. ${ }^{178}$ The broad powers given to officials are justified by the potential losses of public funds and the idea that welfare recipients can be expected to be subject to intrusive, detailed and ongoing surveillance in exchange for the benefits they receive. ${ }^{179}$ Nevertheless, this should not entail that welfare recipients should be subject to detailed background checks or followed by private detectives. ${ }^{180}$

A proportionate use of automated systems also includes a reasonable assessment of the data that needs to be collected in order to establish fraud. There is an inherent tension between the desire for big data to optimize the quality of the risk assessment and the legal rules on data protection that ask for data-minimization. ${ }^{181}$ Especially in the field of social welfare, this tension is eminent, as personal data is the raw material of the benefits system. Recently, the major of Rotterdam refused to use the data-matching and risk-profiling system SyRI because of the disproportionate data-handling. ${ }^{182}$ Less intrusive

${ }_{17} 6$ See M. Button and J. Gee, Countering Fraud for Competitive Advantage: The Professional Approach to Reducing the Last Great Hidden Costs (Hoboken: Wiley, 2013).

177 See J. Milaj, 'Invalidation of the Data Retention Directive: Extending the Proportionality Test', Computer Law and Security 31(5) (2015) 604-617.

178 McKeever (n 21) 141, 150-151.

179 Ibid, at $15^{0-151 .}$

$18 \mathrm{o}$ J. Milaj, 'Privacy, surveillance, and the proportionality principle: The need for a method of assessing privacy implications of technologies used for surveillance', International Review of Law, Computers \& Technology 30(6) (2016) 115-130.

181 See GDPR (General Data Protection Regulation), recital 39: 'In particular, the specific purposes for which personal data are processed should be explicit and legitimate and determined at the time of the collection of the personal data. The personal data should be adequate, relevant and limited to what is necessary for the purposes for which they are processed'.

182 See, for a critical analysis of this system, Gantchev (n 2). 
systems developed by private companies (e.g., Totta Data Lab) to predict fraud continue to be used by other Dutch municipalities. Even though these systems do not make decisions, it is important to underline that whenever risk-profiling is in hands of private tech companies, it becomes extremely hard to assess the proportionality of data collection and the potential reuse of data for commercial purposes as private companies will not allow the public to scrutinize their operations. ${ }^{183}$

Finally, a proportionate use of private actors and their technologies is also important to reduce the longstanding stigmatization of welfare recipients. The widespread use of private automated systems and contracts with private actors is susceptible of promoting a tip-off culture and thus raise not only legal but also ethical questions. ${ }^{184}$ As Virginia Eubanks explains in Automating Inequality, digital tools created to manage poverty, including data mining and automated decision-making, are based on moralistic ideas on poverty that create a high-tech system of policing and containment. ${ }^{185}$ These ideas include the perception that welfare recipients are not entitled to the same degree of privacy and data protection as other taxpayers as they depend on public assistance. This perception is fundamentally incompatible with the principle of effective exercise of the right to social security or social assistance. ${ }^{186}$

\section{$5 \quad$ Conclusion}

In the Atlantic Charter of 1941, social security was defined by its original aim: "the freedom from fear and want." ${ }^{187}$ Nowadays, this statement could not be further away from the reality observed in modern welfare states. This article shows that welfare recipients in different countries have been subject to close private surveillance and that the aim to prevent and sanction welfare fraud has spoken louder than the procedural guarantees and fundamental rights of these individuals. Privatization of public functions is to blame. As Julie Cohen has pointed out "over the last decades (...) surveillance has become increasingly

\footnotetext{
183 See, for an analysis of the potential and legal limits of data reuse, B. Custers and H. Ursic, 'Big Data and Data Reuse: A Taxonomy of Data Reuse for Balancing Big Data Benefits and Personal Data Protection', Internationl Data Privacy Law 6(1) (2016) 4-15.

184 Estrin Gilman (n 147).

185 V. Eubanks (n 14) 16.

186 Gantchev (n 2) 19.

187 M. Westerveld, 'Women and social security', in: F. Pennings and G. Vonk (eds), Research Handbook on European Social Security Law (Cheltenham, UK and Northampton, Mass: Edward Elgar, 2015) 257-280 at 259.
} 
privatized, commercialized (...) and it has become participatory."188 Nevertheless, the outsourcing of powers to private actors should not mean that these powers are expanded beyond what public actors were allowed to do or that accountability and proportionality assessments are bypassed. As Catherine Donnelly explains: "Given that the power does not change when transferred from public to private, it is difficult to understand why the controls on the power should be different: control should depend on the nature of the power-not on the identity of the power-holder."189

The involvement of private actors and the use of automated systems developed by private technology companies illustrate new dimensions of the growing privatization movement: on the one hand, governments seek to optimize their systems, become closer to the citizenry, offer a fair allocation of services, and stimulate citizens to participate and contribute with their knowledge. On the other, by relying on informants, private detectives and digital technology, governments are stigmatizing welfare recipients. In this context, public authorities delegate directly or indirectly the tasks of predicting and detecting fraud to private actors not only to save public money but also to expand their access to information about welfare recipients.

The examples analyzed in this article contribute to the international literature by showing the risks of expanding the outsourcing of public tasks to the private sector under indeterminate legislative and contractual conditions, limited public supervision, and reduced transparency of automated systems. The outsourcing of welfare fraud investigations to private actors with almost unconstrained investigation instruments risks converting public law enforcement into a system where poverty is almost criminalized. We contend that from an expertise point of view, social welfare fraud detection may not easily justify the unlimited outsourcing of public law enforcement to private actors with the risks thereof. The same applies to the employment of private actors to investigate welfare fraud and create risk profiles using big data and predictive analytics. The outsourcing of these tasks to private companies raise constitutional concerns which include the violation of the right to respect for private life, equal treatment (e.g., due to the risk of discrimination resulting from profiling), and the right to a fair trial. Drawing on the case law discussed in this Article, we argue that public law and its procedural guarantees should

\footnotetext{
188 J. Cohen, 'The Surveillance-Innovation Complex: The Irony of the Participatory Turn', in: D. Barney et al (eds), The Participatory Condition in the Digital Age (Minneapolis: University of Minnesota Press, 2016) 207-226.
}

189 Donnelly (n 9) 351. 
be applied to welfare fraud investigations, regardless of who is conducting the investigation, as long as public and private actors are working together.

This article does not aim to argue against the outsourcing of public tasks to private investigators as such an idea would be unrealistic given the benefits offered by private detectives. ${ }^{190}$ Rather, this article offers considerations that could help national legislators reflect upon the proportionality of outsourcing decisions and the need to design adequate legal and contractual framework for the privatization of public enforcement in areas of social policy. This framework should take into account a number of aspects such as when, how, and under what circumstances anti-fraud prevention and detection tasks may be automated and outsourced to private agents.

Many of the objections raised to automated systems developed and used by private companies and detectives would also be valid against public bodies. Nevertheless, the reliance on private actors and technology further enhances the opacity of the decision-making process, the incentive to draw inferences from historical data and biases to find fraud, and set aside the public interest and safeguard of fundamental rights.

In addition, as Matthew Stephenson points out, it is important to also ask "which organs of government ought to be involved in the creation and definition of private enforcement rights." ${ }^{191}$ Finally, "social welfare spies"—-regardless of whether they are public or private actors-should not subject welfare recipients to a dehumanized state of permanent surveillance where tipping-off neighbors is encouraged and where welfare recipients' privacy is worth less than that of other citizens. Rather, new forms of privatization should still be proportionate, legitimate, and imbued with public values. Automated systems used in this context should be trained to limit negative human rights impacts (e.g., discrimination), offer meaningful transparency measures, and allow citizens to rely on public assistance without losing the right to a private life..$^{192}$

\footnotetext{
190 Button (n 28).

191 M.C. Stephenson, 'Public Regulation of Private Enforcement: The Case for Expanding the Role of Administrative Agencies', Virginia Law Review 91(1) (2005) 93-173 at 106.

192 D. K. Mulligan and K. A. Bamberger, 'Saving Governance by Design', California Law Review 106(3) (2018) 697-784.
} 